This is the accepted manuscript of the article, which has been published in

British Journal of Middle Eastern Studies. 2019, 46(4), 663-680.

https://doi.org/10.1080/13530194.2018.1456903

\title{
The good, the bad and the ugly: narrating social bonds and boundaries in contemporary Lebanon
}

\section{Lefort Bruno}

Tampere Peace Research Institute (TAPRI), School of Social Sciences and Humanities, University of Tampere, Tampere, Finland

Department of Contemporary Studies, Institut Francais du Proche-Orient (IFPO), Beirut, Lebanon

Email: bruno.lefort@staff.uta.fi

(C) 2018 British Society for Middle Eastern Studies

\begin{abstract}
The study of political leadership in Lebanon has most often revolved around the questions of the attributes and networks of leaders commonly considered within the frame of patron-client relations. In this empirical article, I propose to shift the focus towards the dynamics of identification at the centre of the nexus between leaders and followers. Focusing on the case of the recently elected president of the Republic, Michel Aoun, I draw on testimonies collected among his supporters to expose how his character instigates acts of affective memorialization. Voicing manifold social inspirations, both private and collective, these memory practices anchor the attachment to the leader into multiple temporalities and emphasize contrasts with alternate repulsive figures to perform social bonds and boundaries. The stories composed around this cast of characters illuminates the historical as well as emotional processes at the heart of political identification in Lebanon.
\end{abstract}

On the 31 October 2016, after more than two years of vacancy at the head of the State, the Lebanese members of parliament finally reached an agreement to elect Michel Aoun president of the Republic. Like many among today's political elite, the figure of this former general in chief of the national army emerged during the wars that devastated Lebanon between 1975 and $1990 .{ }^{1}$ He consequently suffers from the same ambiguous image as the rest of the clique that has dominated the country's governmental life for the last twenty-five years. On the one hand, they embody the deadlocks of the Lebanese sectarian order that nourishes a quasi-perpetual institutional crisis. As such, they personify the intergroup conflicts that ravaged the country and crystallize the animosity of vibrant civil movements. ${ }^{2}$ On the other, these leaders maintain a strong popularity and a capability to mobilize unmatched in the country.

Using this ambivalence as its starting point, this article explores the role of political figures in the construction and performance of communalities in Lebanon. The study of leadership in Lebanon 
has commonly revolved around the notion of za'im, a patron supported by a local community. ${ }^{3}$ Traditionally, the za'im combined political and economic powers over a given territory, either in the city $^{4}$ or in the countryside. ${ }^{5}$ Because of their intermediary position, in-between the State and the populations, these leaders have been closely associated with the sectarian rule prevailing under the French Mandate. However, several factors have led to profound alterations of the structures of the Lebanese leadership. From the 1950s, the 'Silent Revolution' introduced by modern capitalism ${ }^{6}$ and the long march toward the individualization of society deeply impacted clientele networks. ${ }^{7}$ The 1975-1990 wars accelerated these trends by isolating local go-between figures to the benefits of militia leaders. ${ }^{8}$ More recently, the strong political tensions between large national coalitions have favoured nationwide parties, undermining the influence of local notables. ${ }^{9}$ If these evolutions of the system of za' $a m a$ ' have generated many debates, ${ }^{10}$ to the point of even questioning the pertinence of the concept in today's Lebanon, ${ }^{11}$ it remains that the study of political leadership in Lebanon has continued to revolve around the classical issues of leaders' attributes and networks. In this empirical article, I propose to shift the focus towards the interplay of 'reception and identification' that lies at the centre of the nexus between leaders and followers. ${ }^{12}$ In his seminal work on leadership, Max Weber already insisted on this relational dimension, ${ }^{13}$ suggesting that 'charismatic appeal is validated through the perceptions of the followers'. ${ }^{14}$ Accordingly, instead of trying to identify the features of what would be a 'truly charismatic political leader', ${ }^{15}$ we should go back to understanding leadership as an interactional process. In that perspective, to better comprehend the influence of political elite and, beyond, the mechanisms governing the Lebanese polity, I intend to shed light on the construction of leadership bonds themselves: how are political leaders depicted and narrated by their followers? How do these narratives about the relations to the leader inform the modalities of the construction of attachment? To what extend do they enable to understand political communalities in contemporary Lebanon?

To answer these questions, I focus on the case of Michel Aoun ${ }^{16}$ and expose how his followers mobilize stories composed around his character to perform their attachment to a distinctive communality. I rely on ethnographic material gathered during my doctoral studies (2007-2013), mainly photo-elicited interviews collected among around forty sympathizers and officials of Aoun's party, al-tayyâr al-wațanî al- hurr (the Free Patriotic Movement, FPM). Participants were interviewed not from a list of questions like in traditional semi-structured interviews, but using a portfolio of photos instead. ${ }^{17}$ Photo elicitation enables at the same time to learn from and empower a given social group in a collaborative way, ${ }^{18}$ giving them liberty to express their views. The succession of photographs in the portfolio also gives the impression of 'a family album' ${ }^{19}$ populated by 
identifiable figures and building bridges between past and present. Following a micro-sociological approach, the personal testimonies mobilized in this article are not to be considered as representative but rather as examples to illuminate dynamics emerging from my data. The material has been processed using an interpretative approach inspired by the sociology of knowledge ${ }^{20}$ and highlighting 'narrative identities'21 to understand how people's sense of identity is performed through the composition of stories. In other words, I am not so interested in the veracity of the descriptions I collected but rather in the 'symbolic universe', ${ }^{22}$ they sustain. Drawing on this material, I argue that the figure of the leader emerges as a 'lieu de mémoire"23: it is mobilized in storytelling to allocate specific meanings and affects to past episodes. ${ }^{24}$ These acts of affective memorialization built around the character of Michel Aoun voice private and collective stories used to stage social bonds and boundaries. Fueling dynamics of cognition and recognition, they elucidate the nature of political ties in the Lebanese complex society.

After briefly introducing Michel Aoun and the FPM, I turn towards the representations of his leadership among his followers. Portrayed as a (grand-)father, a hero, and a prophet, his figure articulates multiple voices and temporalities. However, Aoun's character only acquires its full meaning in contrast with two alter-egos: Samir Geagea, his negative double, and Bachir Gemayel, portrayed as Aoun's historical predecessor, but whose representations are stained by his bad deeds and ultimate failure. Together, these three characters - the Good, the Bad and the Ugly - offer a contrasted casting that highlights the dynamics of political communalities in Lebanon.

\section{Michel Aoun in the FPM identity narrative}

Stories about Michel Aoun operate primarily within a specific memorial repertoire composed in reference to one of the last episodes of the Lebanese wars: Aoun's nomination at the head of a transitional military government in September 1988. Then commander in chief of the army, Aoun was designated by the departing president of the Republic Amine Gemayel to avoid the vacuum at the head of the State in a country that has been gradually broken down. Since 1975, state's attributes have been taken over by militias and local armed groups, and both the Syrian and the Israeli armies controlled parts of its territory. Immediately after is nomination, Aoun claimed his intention to reestablish the State authority against both the Syrian armed presence and the many powerful militias, especially the Christian Lebanese Forces (al-quwwât al-lubnâniyyah, LF). His stands won him significant popular support, materialized by massive demonstrations taking place around the presidential palace in Baabda, where the General had his headquarters. ${ }^{25}$ Yet, politically isolated despite his popularity, Aoun was finally evicted by a Syrian military operation on 13 October 1990. 
Forced to exile in France, he encouraged his followers to set up clandestine civil movements against the Syrian presence in Lebanon. Pro-Aoun activists played a central role in the popular demonstrations that forced the withdrawal of Syrian troops in March 2005, paving the way for the General's return. A few months later, in September 2005, Aoun officialized the creation of his political organization, the FPM. Presented as a secular party campaigning for the renovation of the political system, the FPM rapidly gained support in all Christian populated areas. Since the 2005 parliamentary elections, it has been the largest Christian component in the Lebanese sectarian institutions.

Among Aoun's supporters, his term at the head of the State between 1988 and 1990 became a myth. They sublimated his proclaimed fight for the 'liberty (huriyyah), sovereignty (siyyâdah) and independence (istiqlâl)', denying the fact that in his attitude as well as in acts, Aoun appeared to be yet another warlord concerned with his own supremacy. ${ }^{26}$ Moreover, the military government was actually only exercising its influence over what was then called the 'eastern territories', a region of approximately 2000 square kilometres in central Lebanon, mostly populated by Christians. Similarly, beyond the claims of intergroup coexistence in Aoun's army, his units were made up of a large majority of Christian soldiers. ${ }^{27}$ Despite his defeat, the figure of the rebellious general was further glorified among his followers during his exile. Paradoxically, his absence strongly contributed to forging his iconic dimension. Following the creation of the FPM, this romanticized story became part of the party's 'social imagination'. ${ }^{28}$ Celebrated in the FPM as well as in its media networks, the official narrative of Aoun's quest follows a specific plotline with biblical overtones: a lost paradise, a time of harmony between the leader and his people as they confronted the double threat of militias and Syrian troops (1988-1990); the Fall of 13 October 1990, when the General was forced to surrender; the Purgatory of the exile before the final resurrection symbolized by Aoun's return.

This official story, however, coexists with a multitude of personal memories, with which the organizational narrative necessarily interacts. To understand the nature of the bonds constitutive of the FPM, it is then necessary to decrypt the dialogue between official partisan storylines on the one hand, and private memories on the other. To do so, I chose to concentrate on memory practices ${ }^{29}$ among FPM supporters. Starting from personal evocations of the leader allows tracking the influence of collective discourses and exploring how both organizational and individual imaginaries are combined to produce a multivocal narrative about the leader and, beyond, the social group that he is said to represent. While they primarily focus on past episodes, these evocations have to be understood as reconstruction, composed in the time of storytelling. Indeed, as Maurice Halbwachs claims, it is the affection of the present that is projected into the horizon of the past. ${ }^{30}$ Accordingly, I suggest that 
attachment to the group is realized through the narrative construction of a 'joint presence', defined as the narrative projection of the self into a collective story inspired by the interplay between private memories and group feelings and experienced as 'an affectivity of resemblance, , 31 an emotionally grounded conviction of sharing a common position in this collective tale.

\section{The temporalities and affectivities of attachment}

Presented with a photo of Michel Aoun, FPM sympathizers voiced stories that materialized their attachment to the leader and the Party alike. The systematic use of this visual prompt allowed the collection of contrasted narratives illustrating the plurality of experiences coexisting within the FPM. This diversity seems nonetheless transcended by the recurrence of patterned repertoires: a patriarchal family album, a heroic tale, and a prophetic legend. While these repertoires are typical tropes, what is more interesting is that each of them relies on a particular affective attachment and anchored in a specific temporality.

\section{$\underline{\text { The (grand-)father: an affectivity of fusion }}$}

On Beirut's Sassine Square stands a monument erected to commemorate the assassination of Bachir Gemayel in 1982. At the terrace of a café right under the memorial, Bachir, a FPM official then in his 30s, smiled as he discovered the photo of Michel Aoun:

Michel Aoun is a symbol. It is not possible to envisage the FPM without him. So he is the father of a new vision of Lebanon (...). [...] My feeling [when Aoun returned from France] is similar to the one of a child who did not feel safe because his father wasn't there. And then he comes home. We immediately felt safe. We thought that this guide, this leader was finally back among us (...) and that everything is going to be all right. [Bachir, FPM regional coordinator, 5.5.2005, Beirut]

Born in 1977 in Senegal, Bachir came to Lebanon with his family at the age of 9. Landing in the chaos of militia fighting, he recalled the rise of Michel Aoun as 'a new beginning'. Immediately identifying Michel Aoun as a symbol, Bachir stresses the correspondence between the Party and its leader. But it also introduces followers as 'children' in need of the supervision of their father to ensure their own security and guide their path. The account exemplifies a sense of fusion between the followers and the leader. The interpretative repertoire, centred on the domestic semantic field, composes an organic bond and naturalizes the relation of leadership. In that perspective, attachment is primarily mediated by the construction of a joint social body. As Maroun and Johnny, two student activists in the FPM, both explain: 
When you visit him in his house, you are at your grandfather's place. You are not meeting with a big sectarian leader (...), you are really with your grandfather, who greets you. (...) He himself offers you candies and inquires about your studies. [Maroun, student, 6.11.2007, Beirut]

$\mathrm{He}$ is actually rather small. When you see him, he really looks like a grandfather. You can feel that he is genuine. Usually, grandfather are sincere, they don't lie. He is exactly like that. [Johnny, student, 9.12.2009, Beirut]

Michel Aoun is portrayed as a paternalistic figure, close to his children and concerned about their future. Characteristically, the representation of the leader as a (grand-)father emerges from personal souvenirs mostly related to biographical experiences. Attachment to the leader here relies on intimacy, as exemplified by the frequent display of photographs of the General in the privacy of activists' house or room. ${ }^{32}$ Logically, first encounters with the leader are usually recalled in details, as the testimony of Elsa, a young employee of the FPM radio station sawt al-mada, illustrates:

In the summer [1998], I travelled to France to my aunt's place. In the plane, I met a dozen of Aounists who were going to visit Michel Aoun (...). We had a drink and someone proposed a toast to the General. I wanted to show them how much I love him and emptied my glass so fast that I felt dizzy [laughs]. (...) They had given me his number and when I called for the first time I immediately hung up as soon as I heard someone answering. I was so nervous. I did it maybe five or six times before I was able to speak to him. (...) But when I did, he talked to me for fifteen minutes and I forgot that he was Michel Aoun, the great character. He talked to me, a young 16-year-old girl, with simple words. I felt that I had known him for a long time. (...) When I went back to Beirut, I joined the FPM and I will work all my life for the Party. [Elsa, journalist at Sawt al-Mada, 17.11.2007, Beirut]

The joint presence here operates as a projection of the self into a common family album, articulating personal anecdotes to the partisan storyline. Followers revisit their souvenirs to describe an organic bond unifying them to their leader and perpetuated across generations as the transition between images of father and grandfather shows. This repertoire sustains an affectivity of fusion that deploys itself in biographical times. However, this family album acquires its full meaning against the backdrop of a greater story in which the patriarch of the family is also the central character.

\section{The hero: an affectivity of inspiration}

At the terrace on Sassine Square, Bachir appeared never to be short of words when it came to 'the General'. He had been talking for almost half an hour with great animation and had barely touched his coffee. As the conversation turned to his career inside the FPM, he added:

Getting to know someone like Michel Aoun changes the image you have of him. Your perception evolves toward something much more rational. (...) You still admire him, but 
you also respect him and listen to him in a much more scientific way (...). In a word, you are less in love with the man but more in admiration for the character. [Bachir, 5.5.2008]

The organic bond experienced with the leader is here doubled with the affirmation of a political adhesion to his cause, which intends to rationalize and objectify the sense of attachment. The weight of the organizational discourse looms as followers celebrate the achievements of Michel Aoun and turn him into a popular hero whose quest is a source of inspiration:

For me, [popular mobilization in Baabda] had the meaning of human shields: people came to give their lives to protect the General because they had found in him a symbol and an inspiration to survive. He appeared as a liberating hero. And indeed, a vast majority of the people identified with him. [Bassel, FPM committee of Political Education, 21.10.2008, Jbeil]

To understand the popular support from which the General benefitted during his term at the head of the military cabinet and the way it was popularized in the FPM's narrative identity, it is useful to go back on the context prevailing at the time. Aoun's designation constituted a point of inflection in the history of the Lebanese wars, in particular for the populations living in the 'Eastern areas'. In the early 1980s, after the breakdown of the State, the LF militia established an almost homogenized communal territory through the forced unification of Christian populations, the expulsion of nonChristians, and solidification of the borders with the other militias. ${ }^{33}$ Eager to construct a community of its own, the LF morphed into an apparatus of domination, growingly agitated by violent internal conflicts. ${ }^{34}$ Amid this chaos, Aoun's claim to restore legality received a positive echo and became engraved into the FPM official memory:

I remember one day during the war, there was a fuel shortage. (...) We were with my mother at a gas station when we saw militiamen [from the LF] coming. They moved everybody aside and started to fill gallons of fuel. The owner of the station called the Army, which had recently taken charge of the country under the leadership of general Aoun. When the soldiers arrived - I always remember this - they organize everything. Everyone was able to take gas in turn and everybody was happy. There was no chaos anymore. [Alain, bank employee, former FPM official, 20.11.2007, Beirut]

This image, of course, is largely embellished. From the beginning, the legality of the interim military government has been contentious. Because Aoun is a Christian Maronite, his designation was controversial as the custom established by the 1943 National Pact reserves the position of to a Sunni Muslim. Moreover, the three members of the military council representing the Muslim sects (one Sunni, one Shia, one Druze) refused to join the cabinet. Aoun's government was therefore limited to three Christian officers, in contradiction with the country's consociational regime. Yet, it remains that 
Aoun's accession to power introduced a rupture in the status quo of the time and thus deeply marked the lives of the populations living under the Army's rule:

In 1988-1989, my father was a soldier. He lived through all the battles of Lebanon (...). It nourished our rebellion against this war (...) I rebelled against everything and I found the General with his spirit of revolt and this will to liberate all the Lebanese. I gave me the enthusiasm to engage into activism (...). It was an answer, an answer to what we were experiencing (...). [Paula, psychologist, FPM regional branch, 4.5.2008, Zahleh]

In Paula's words, Aoun is introduced as an impulse, the inspiration explaining her engagement, past and present. A military - like her father - he is said to have played the role of a catalyst, unifying people around a common cause. In this retro-projection of the past, the joint presence arises from the staging of the self into a partisan legend. Memories describe a historic bond, grouping people around their leader and his quest. This repertoire sustains an affectivity of inspiration that revolves around a specific interpretation of the internal conflicts that devastated the country in the 1980s. Rather than on biographical times, it operates within a wider time scale.

The bonds asserted in these testimonies are not primordial like in the family trope but instead elected. They perform the adhesion to present political stands, using a romanticized vision of the past. Today, the FPM cultivates this memory as the celebrations following Aoun's election at the presidency of the Republic confirm. His sympathizers set up mimetic demonstrations, for example re-baptizing the presidential palace in Baabda 'Palace of the People' (qașr al-sha'b) as it was known in 1989. However, despite these 'imitations and replications' ${ }^{35}$ to stage continuity, the contemporary experience appears divergent from its model. Aoun and the FPM are no longer fighting the status quo. On the contrary, participation in national unity governments since 2008 has profoundly transformed their cause. They have embraced the confessional regime and recently sealed punctual alliances with other politically rival Christian forces in the name of the defence of the community. In 2015, Aoun also imposed his son-in-law, Gebran Bassil, at the head of the FPM. In a word, the FPM has become an ordinary party in the Lebanese political field, thriving on sectarianism and familial heritage. This trend underlines a last dimension in the representation of Aoun's figure: his status of communal leader.

\section{The prophet: an affectivity of communion}

As the conversation with Bachir went on, it turned to the Document of Understanding concluded between the FPM and Hezbollah, the powerful Shia organization. The young man voiced unconditional support for the partnership that was secretly negotiated and took many by surprise. At the time of Aoun's return, antagonism between the two political forces seemed irreversible. 
Internally, Aounists advocated a secular regime, whereas Hezbollah's ideals were inspired by Khomeyni's thought. Externally, while Hezbollah had become supportive of Damascus' role the region, FPM activists had embodied for years the refusal of the Syrian domination over Lebanon. Yet, in February 2006, Michel Aoun and Sayyed Hasan Nasrallah met in Mar Mikhail Church situated on the former frontline to seal their agreement. According to Bachir, the move was crucial:

As I see things, facing the threats caused by the implantation of Palestinians and the various al-Qaida factions, which are Sunni, I consider that Hezbollah stands as a protector for me, as a Christian. It's a protection against Palestinian militias and terrorist groups financed by oil money. [Bachir, 5.5.2008]

Bachir's comments posit the sectarian dimension of Lebanese - and beyond, Middle Eastern politics. In doing so, he convokes the memory of antagonism that existed between Lebanese nationalist, among which Christians were predominant, and Palestinian fighters back in the 1960s. In that perspective, Michel Aoun and the FPM are depicted as new avatars of an ancestral struggle between religious groups. Many among Aoun's sympathizers share these views, including among the youth who did not directly experience the conflict with the Palestinians:

I am only 21 years old, so my contribution to the cause is limited. Because people have started to engage since 1969 against the invasion of the Palestinian militias (...) and then the Syrian army until 1990. Afterward, militants have turned into civil activists. (...) So many people between 1969 and 1990 paid the price of their engagement with their lives and blood. (...) I only participated in the last stage, and in a very limited way. [Maroun, 6.11.2007]

Maroun situates the FPM into a longer historical sequence, associating Aounism with the 'refusal front' incarnated by the Lebanese movements that opposed the Palestinian armed presence in Lebanon legitimized by the 1969 Cairo Agreement. In doing so, he clearly positions the FPM into the realm of Christian nationalist political stream that has dominated Lebanese politics since the formation of the country. ${ }^{36}$ The evocations of the leader as a communal figure demonstrate how the religious repertoire participates to the construction of attachment:

Michel Aoun is the leader of the Christians ... their political leader. There are two leaders for the Christians now: one religious - he is powerless (...) - and one political. And until now, there is no one who is like him. (...) He is a man who sees what is going to happen in 20 years, whereas all the others need 20 years to think. [Johnny, 19.12.2009]

[Aoun] is a good leader. He looks forty years ahead. (...) It's not only my thinking, the facts show that his decisions proved to be the best decisions. (...) He fulfils the role the Maronite Patriarch should play. Michel Aoun is our Patriarch. (...) Within fifty years, the Muslims will be far more numerous. (...) I am scared of that. It will be a matter of time before there are no Christians left. [Nadim, born in 1987, student, 9.3.2011, Beirut] 
Aoun is depicted as a visionary, able to read history and thus protect the Lebanese Christians. The opposition constructed between Aoun and the Patriarch echoes the paradigm of the âmmiyyât, ${ }^{37}$ which interprets the political dynamics among Christians on the basis of the evolution of the power relations between the Maronite religious authority, the political leaders from within the community, and the masses. ${ }^{38}$ Historically, the Patriarch's pursuit of temporal power nurtured the rivalry with the secular elite. This rivalry escalated after the establishment of the French Mandate, which triggered a decrease of the Church political authority. ${ }^{39}$ From 1988, the General has maintained troubled relations with the religious leadership of the Maronites. The Patriarch exhibited much reservation toward the popular movement that emerged in Baabda. Mutual mistrust reached its climax on November 5, 1989, when a group of Aoun's sympathizers molested the Patriarch in Bkerkeh. ${ }^{40}$

Aoun himself has played on religious references, proclaiming himself 'Patriarch of the Christian street'. ${ }^{41}$ The Party has also promoted his image of defender of the Christian heritage in the Middle East by organizing pilgrimages in Syria at the occasion of the Day of Saint Maroun, the founding father of the Maronite monastic order. In 2009 and 2010, in an attempt to capture Christian legitimacy and to mark his rapprochement with the Syrian regime, Michel Aoun decided to celebrate the Saint in his supposed burial place, near Aleppo. ${ }^{42}$ These journeys associated political aspects e.g. meetings with Bachar al-Assad - and communal dimensions:

Nine thousands people went with him to Syria! (...) He sent a message to the Christian in Lebanon: 'We are not alienated, we belong here'. Before, we only thought that we were Christians, leaning toward Europe and the US rather than the Middle East (...). His idea is that yes, we are Christians, but we are home here. [Clara, student, trainee at Sawt al-Mada, 12.3.2011, Beirut]

These symbolic gestures go along with a progressive shift in the FPM from a secular ideology towards a 'Christianization' of its stands. ${ }^{43}$ Such an evolution is not without causing dilemmas for many activists:

I was in Baabda, during the demonstrations in front of the Palace of the People. (...) It's part of my youth, a bit naïve and idealized. (...) Then I found that this man who spoke about secularism became a Christian leader like another. (...) It is disturbing for me (...). I think that he fell into the trap of sectarianism [Carole, journalist and activist, 8.3.2011, Beirut]

A troubled regional context played a part in this evolution, reactivating in Lebanon the memory of past episodes of religious violence, in particular the nineteenth-century massacres, known as the harakât. ${ }^{44}$ These confrontations deeply impacted the modern political identity of the Maronites ${ }^{45}$ and its link with Lebanese nationalism summarized in a famous quote of Istfan al-Duwayhi (1629-1704), a clergyman and historian: 'The Maronite community's history is a continuous struggle to maintain 
national and religious identity in a dominant Muslim environment ${ }^{,}{ }^{46}$ Re-injected in several moments of the Lebanese wars between 1975 and 1990, the reference to inter-communal violence has been perpetuated by the fierce political oppositions prevailing in post-2005 Lebanon. It has taken the form of a common belief cultivated within the FPM in a 'Wahhabite conspiracy' orchestrated by Saudi Arabia and implemented by Sunni political movements. This conception arises in many pamphlets and publications circulating among partisan networks. A short book written by Lyna Elias and emphatically entitled 'The Christians of Lebanon Threatened of Extinction or the Plan for the Islamization of Lebanon Has Started' provides a good illustration. ${ }^{47}$ Costing the modest amount of three dollars (4,500 Lebanese Pounds), it intends to resituate the current political situation of the Christians into a wider historical perspective to demonstrate the existence of a US-backed plot to ensure the implantation of Palestinian refugees in Lebanon at the expense of the Christians. In that horizon of thought, Michel Aoun becomes a Prophet, guiding Christians and not only FPM followers toward a better future:

There is something I always remember about General Aoun. I am originally from the South. My family moved [their electoral inscription] to Achrafiyeh [Beirut's Christian district] but I am the only one in my family who stayed registered in the South for the elections. (...) Once we went with many other people from the South (...) to General Aoun's place and a student told him he wants to change his registration so his vote will be more important. General Michel Aoun shouted at him: 'I am trying to get you all back to your land, and you are trying to leave it?!' [Malek, born in 1988, coordinator of the FPM in the American University of Beirut, 26.5.2010, Beirut]

In these words, the leader is constructed as the embodiment of the Christians' attachment to their territory. Activating an affectivity of communion, i.e. a joint construction relying on the belief in a community of destiny, Michel Aoun is symbolically interpreted as a prophet of the land safeguarding the roots of his community and ensuring its survival in a region demographically and politically dominated by Islam. Centred on the fate of the Christians, this repertoire adopts a long-time perspective. It is essentially an affectivity composed along the voices of past violence to activate attachment to a protective figure.

\section{Mediating social boundaries}

Evocations of Michel Aoun play on organic, political and messianic repertoires and multiple temporalities to perform social bonds weaved between the leader and his followers. This multivocality similarly arises in the discussions on two other figures, omnipresent in the stories 
elucidated by FPM sympathizers: Samir Geagea, constructed as a negative duplicate of Michel Aoun, and Bachir Gemayel, whose image supports a contrasted - and contested - narrative continuity.

\section{Aoun's counter-type: Samir Geagea}

As I pulled out a photo of Samir Geagea, leader of the LF and historical rival of Michel Aoun, Bachir's face froze for an instant. After a silence, he uttered, visibly embarrassed:

I could say many bad things. I think he proved that he had no political vision (...), [that he is] short-sighted. So I think he made many mistakes that cost dear to the Christians and to Lebanon. (...) He trusted the US and the Syrians, he divided the Christians, to ultimately end up in jail. (...) He didn't see the Christian community on the long time. (...) Today, he is doing the same mistakes again. [Bachir, 5.5.2008]

Samir Geagea's portrait perfectly mirrors the one of Michel Aoun at the exception that the three repertoires of attachment are expressed negatively. While Aoun instigated a paternal attachment, Geagea prompts aversion. Instead of being depicted as a national hero, he is presented as a traitor, instrument of external powers against the interests of Lebanon. Finally, whereas Aoun was characterized by his ability to see the Future and guide the Lebanese Christians, his rival is said to be 'short-sighted'.

The rejection inspired by Samir Geagea is palpable. The majority of FPM supporters I met expressed the same discomfort when presented with his picture. Ill-at-ease, many are those who asked to conceal the photograph. To understand the mechanism of this rejection, it is useful to look back at the violent competition between the political projects of the two leaders and especially during the frontal war that opposed the Lebanese Forces and Aoun's army units in the first half of the year 1990. This bloody inter-Christian strife is recalled as harb al-îlghâ' (the elimination war), a term coined by Samir Geagea, and used mainly - though not exclusively - by LF supporters:

He has always tried to be a leader, but never succeeded. (...) Since he took control of the LF, there was an inter-Christian war. Although they pretended to protect the Christians, he killed them, he starved them, they raped Christian women, and they murdered their own brothers. If you want an example, once a LF militiaman (...) was on drugs and he killed his own brother, born from the same father and mother, who was a soldier in [Aoun's] Army (...).

- Where did you hear that story?

My parents told it to me. They knew all the families from the village and in one of them, one son was in the LF and one in the Army. It happened of course in many families. But they knew this particular one in which one militiaman killed his brother (...). [Karim, student, 21.3.2011, Beirut] 
The trope of the intra-family fighting, central in Karim's story, clearly mirrors, in a negative form, Aoun's father-like figure. The murder of the soldier by the militiaman - and not the contrary connotes the disloyalty of Geagea. The 'Elimination war' is still interpreted today as a betrayal coming from inside the same 'house'. The inter-Christian fighting, one of the bloodiest phases of the wars, ${ }^{48}$ effectively torn families and separated neighbours, and remains a traumatic event in the memory of the population living in the contested area. 'With the LF, we cannot be reunited (...) because of the war. If I killed your father, you will never go back to me (...). On the contrary, between us and Hezbollah, there is no blood ${ }^{49}$ once told me Laura, a student sympathizing with the FPM. Having built his legitimacy on slogans like 'No to the statelets, yes to the State' ${ }^{50}$ Aoun could not get along with a force constituted against - or as substitute to - the State. Beyond these postures, Samir Geagea and Michel Aoun more fundamentally acted like two warlords in competition for the same territorial and political space. ${ }^{51}$ Coexistence was logically impossible. This wartime opposition turned into a founding myth based on a conventional fratricidal trope, similar to the story of Romulus and Remus in the Ancient Rome. The recent political reconciliation at the occasion of the presidential elections between the two leaders is far from having diminished the tensions and resentments between supporters of both organizations.

Ironically, drawing a parallel between the trajectories of the two leaders only gives more impact to their irreconcilable differences. Both are from modest origins but come from opposite environments. Son of a butcher, Michel Aoun was born in the village of Haret Hreik, now part of the Southern suburbs of Beirut, and at that time populated by Christians and Shiites. Samir Geagea also came from a humble family, but Bcharri, his village, known as the homeland of the writer Khalil Gibran, is situated in the heart of the Maronite spiritual centre in Lebanon. It dominates the holy valley of the Qadisha, which fosters innumerable monasteries, convents, and churches. While Michel Aoun joined the Army in 1954 and slowly climbed the hierarchical ladder, Samir Geagea medical studies were interrupted by the war. According to Sune Haugbolle, Geagea's ascension incarnates the turn in the structure of leadership between the traditional zu'amâ' and the new militia leaders imposed by the war, as his 'legion of Northern Maronites was introduced onto the streets of East Beirut where they were met with suspicion and scorn'. ${ }^{52}$ This distinction between centre and peripheries still nourishes Aounists' representations on LF supporters:

They are militiamen. They can only live in a context of violence and blood. I compare them with vampires, only surviving by killing others and sucking their blood. That's why violence in the streets are usually always started by supporters of Geagea. [Bachir, 5.5.2008] 
These evocations adopt a partisan frame to oppose the militia heritage of the LF to the supposedly law-abiding profile characterizing the FPM. It builds on a rhetoric that structured the 1990 war between LF and Aoun's army, i.e. the militia versus the State, the za'rân [thugs] versus the âwâdim [honest people]. Still today, the regional implantation of the LF in Geagea's home region of Bcharri constitutes a strong differentiation with the FPM. If Aounism influenced in priority the population living in the 'Eastern areas', it has carried from the beginning a national project fundamentally different from the LF's wartime plans to establish a communal canton. While Aoun occupied the Presidential Palace in Baabda, centre of the political power in Lebanon, Geagea had established his headquarters in suburban (Qarantina) or Mountain (Mayfuq) areas. The LF leader thus embodies a twofold opposition: politically, between the central State and autonomous peripheries, socially, between 'the Mountain and the City'. 53

Finally, in the ultimate aspect of the mirroring opposition between the two leaders, Samir Geagea is also denied legitimacy to talk in the name of Lebanese Christians.

I don't want to blame Samir Geagea, but he always makes the wrong choices. (...) He keeps changing his mind (...). In 1990, he said he was going to overturn Aoun to become President, and the result is that he went to jail (...). He is someone who doesn't know how to read politics. [Alain, 20.11.2007]

What could I say? Beware if he is to become the leader of the Christians! (...) I believe that without Michel Aoun, there would not be Samir Geagea. He has a complex because the people love Michel Aoun (...). He tries to imitate him but only to guide Christians into darkness. He is a criminal ... [Jacques, student, 30.4.2008, Beirut]

Unable to read History contrary to Michel Aoun, unstable in his directions, Geagea is said to be a danger for the very group he pretends to guide. Samir Geagea hence aliments an affectivity of distinction for FPM sympathizers. He is incapable of instigating intimacy, inspiration, nor communion. On the contrary, he is depicted as the incarnation of Evil and embodiment of the figure of the enemy of the interior:

He is the cancer of the society. I won't say more. A cancer ... for me he is a murderer and a criminal. He doesn't worth talking about him anymore. [Adonis, scientist, 1.12.2009, Beirut]

$\mathrm{He}$ is a criminal and a liar. He has all the attributes of the demon. [Philippe, student, 14.11.2007, Beirut]

As a result of this rejection, in the eyes of most of FPM activists, the opposition between the FPM and the LF presents itself as a naturalized alternative: 
As a Christian, you are either tayyâr [FPM] or quwwât [LF]. And honestly, one can guess from the look. They belong to another class ... they are villains in the true sense of the term! (...) They wear a cross-sword [an emblem of the militia during the war] clearly visible around their neck, they enjoy going down to the streets to claim they belong to them. [Milo, student, 21.10.2008, Beirut]

Yet, the alternative between the FPM and the LF is not as compelling as suggested in the words of Milo. A multiplicity of other possible spaces of engagement indeed exists. Without even mentioning civil movements, many organizations coexist in the partisan field alone, both secular (e.g. Syrian Social National Party, Lebanese Communist Party) or explicitly inscribing themselves in the realm of Christianity (e.g. Liberal National Party). Hence, silencing these options to present the opposition between Aoun and Geagea as the only possible choice has to be understood as a product of the partisan memory, composed in synergy with familial memories from 1989 to 1990 . The post 2005 rivalry between the two groups now competing for the same electoral constituencies has actualized the original meaning of their antagonism and sustained the exclusive social identities born during the 1990 war. The souvenir of the 'militiamen' still has currency because of present-day political competition. What is voiced as a natural translation of religious identities into political affiliations is hence the result of a political positioning.

Lacking the sympathy of a father-like figure, Samir Geagea is also depicted as a traitor rather than a hero and a curse for the Christians rather than their prophet. Words about the former militiaman thus confirm that the three repertoires of leadership work together as a system. Intra-family memories, political history and communal imagination jointly shape the social frames of memory among FPM supporters. This triple context sketches the construction of attachment, voiced in reference to geometrically variable groups (family, party and sect) but experienced as making of a FPM identity. This multivocality of attachment is also perceptible in the testimonies on another prominent figure: Bachir Gemayel.

\section{The Equivocal Heritage of Bachir Gemayel}

Bachir had been talking for almost two hours when we reached the last picture of the portfolio I used for my interviews, a portrait of Bachir Gemayel. Looking at length at the photograph my interlocutor uttered:

Actually, I was named Bachir after him. (...) I started my initiation to politics with him. But I was very young and I didn't know much. In fact, if you look at his story, he is someone who was able to become a President for all the Lebanese. He was originally talking about the Christians, he even had a Christian militia ... And well, he made many mistakes, like in all other militias. (...) But I prefer not to talk about it, it is the past. (...) [Bachir, 5.5.2008] 
This portrayal reveals a form of malaise, hinting at the many ambiguities of the figure of Bachir Gemayel. Son of Pierre Gemayel, the founder of the Lebanese Phalanges (or Kata'eb), Bachir inherited the political leadership of his father. Joining the Party at the age of 12, he then commanded its student branch between 1965 and 1971. After participating in the first battles opposing Christian nationalists to Palestinian forces around 1975, he became in 1978 the first head of the newly created Lebanese Forces. As such, Bachir Gemayel engaged in collaboration with Israel to train and arm his militants. He was also instrumental in the inter-Christian fighting that broke out at the end of the 1970s. Under the pretext of 'unify the riffle [tawhîd al-bunduqiyyah]', Bachir Gemayel violently imposed his leadership over rival Christian nationalist groups. Two episodes in particular have sedimented in the memory of the Lebanese wars: the violent attack of the bastion of the Franjieh family in Ehden, North Lebanon, in 1978 and the massacre of tens of sympathizers of the National Liberal Party at the Aqua Marina Hotel in Safra, a sea-resort north of Beirut. Logically, the souvenir of his violent attitude imprints the evocations I collected:

Some actually call Bachir Gemayel the 'little nazi'. (...) For me, he was a bloody criminal (...) and the source of all our problems from 1982, after his death. (...) In a way, he was responsible for the aberration of the civil war (...). [Hugo, coordinator in the FPM's student committee, 4.5.2010, Beirut]

Lebanese saw him as a hope, but I didn't live in these times and I don't know much about him. As far as I am concerned, I don't like him. It's said that Michel Aoun was close to him (...). Maybe, but Bachir Gemayel used the support of Israel (...). He committed many other mistakes, like the massacre of Aqua Marina, when he ordered the murder of many supporters of the Ahrâr [the National Liberal Party]. [Jacques, 30.4.2008]

Bachir Gemyel's militia past as well as his attitude towards Israel are seen as incompatible with the qualities of leadership promoted within the FPM, all the more since many of Aoun's first supporters have come from families affiliated to political parties that have been marginalized under the domination of the LF. However, Gemayel's ascendency to the presidency of the Republic was marked by a transformation of his discourse from Christian nationalism towards more inclusive stands to charm Muslim populations and leadership, in particular immediately before and after his election in the summer 1982. Designated President under the auspices of Israeli armed forces that were at the time besieging Beirut, he proclaimed his will to re-establish the authority of the State over all the Lebanese territory. Assassinated only a few days later, on September 14, 'Bachir' was erected to the status of a national martyr. The consequence is that his figure carries some similarities with Aoun's patriotic tale and is thus difficult to grasp univocally for most of FPM sympathizers: 
I have mixed feelings. (...) I was never on his side (...). But after his death I reevaluated his action in a less negative way. (...) Many see in Michel Aoun a Bachirian figure, but not me. (...) Bachir is too Christian, in terms of identity. On the contrary, Michel Aoun is more universalist and ecumenical (...). [Bassel, 7.3.2009]

He was a leader able to unite all its supporters, from all the constituencies, Christians and Mulims. He had a vision for Lebanon but we lost him. We cried when he was elected President because he was a central character in the black years (...), a criminal. (...) But when he was elected, he succeeded in uniting people. He forbid his militiamen to march on the streets with weapons and prohibited fights in schools and universities (...). He tried to put Lebanon back on track, to stop the war. But he couldn't. (...) So we cried when he was elected but then we cried when he was assassinated. [Adonis, 1.12.2009]

Gemayel's late pro-State stands are commonly valued in spite of the ambiguities of the character. Parallels with Aoun arise more readily for activists who have been educated in Phalangist families like Elie, a young executive in the FPM youth section whose father had been an activist in the Phalange:

He is someone who committed many mistakes, but it is also a martyr, someone who created a dream like Michel Aoun did (...), the dream of a free Lebanon. (...) For me, Bachir Gemayel is 1982, not 1977 or 1978 . He is not the one who represented the LF but all the country, Christians and Muslims. (...) My father told me that there were only two moments in History when Lebanon was not corrupted: in 1982 after the election of Bachir Gemayel and in 1988 with the rise of Michel Aoun. [Elie, FPM student committee, 20.4.2008, Beirut]

The reference to a dream comes from a well-known slogan used by Gemayel at the time, hinting at relatively intimate knowledge of the figure. In spite of that, the incompatibilities of the character with the FPM political imagination (especially his violent past and affiliation to an elite family) force people to craft some arrangements, using various rhetoric devices to value specific aspects while acknowledging the many mistakes and ultimate failure of the character. It is most probably the partisan frames of memory, and more exactly their anti-militia anchors, that impedes total endorsement of the figure of Gemayel while the Christian political memory frame seems more ready to integrate his figure as a link in a longer chain of prophets. However, this dissociation appears to be overridden in two configurations: when family or local heritages are strongly valuing the memory of Bachir Gemayel. Territorial influences offer a typical and heuristic example to understand the influence of mutivocal memory in the construction of attachment. Among FPM supporters who highlighted the most the character of Bachir Gemayel were three activists originating from the city of Zahleh, in the Eastern part of Lebanon, and belonging to three successive generations:

Bachir, when he died, I was the first to go down to the streets of Zahleh with candles (...). (...) These two [Gemayel and Aoun] are our faith in Lebanon (...). Bachir was our revolt, 
the revolt of our generation (...) and our hope, in particular for the Christians. He gave us faith in ourselves. (...) We know that Bachir wasn't pure, that he did ugly things, that he was in relations with Israel. But he had his reasons, mainly the fear of the Palestinian presence. (...) The General is the image of Bachir, but a picture that could be fully developed. He is the fulfilment of this conviction, of these ideas, of this vision. (...) We remember Bachir through the General (...). [Paula, 4.5.2008]

In this account, Paula asserts that Aoun's project arose as an improved extension of Bachir's. The ambivalence of Bachir, who 'was not pure', is transcended by Aoun's continuation of his dream. In this perspective, Aoun's success reflects on Bachir's image, granting him an acceptable portrait notwithstanding the consciousness of the mistakes he committed. Her narrative therefore bridges two stages of her life, two moments of identification pivotal in the process of construction of herself. In a comparable manner, Georges, born ten years after her in the same city, claims the legitimacy of the heritage of Bachir within the FPM.

He is a character who is legitimate in the FPM. (...) He is often criticized in the party (...) because $(. .$.$) he was a militiaman. But he was also a leader who gave a dream for the$ Lebanese people, especially the Christians, to end occupation by foreign troops and build a strong Lebanon. (...) I love him. I have critical comments as he played the game of blood, but he had great ambitions for the country. I think the true heirs of Bachir are now in the FPM. For instance, when Bachir was fighting against the Syrians, he used to talk like a Prophet and to say that defeat is not to have the enemy at our gates, in our villages (...). The true defeat is when we are vanquished in our souls (...). These words came back in October 13, 1990, when Aoun was ousted by the Syrians (...). I think he is a great resistant. (...) My family is mostly Phalangist and for us, Bachir is a hero. There were pictures of him in our home and still today I have one in my room. (...) I have one picture of him and one of Michel Aoun. [Georges, journalist, 6.3.2009, Sin el-Fil]

Because of the memory of his family, marked at the same time by his socialization within the Phalangist party and by the strength of his local roots in the city of Zahleh, Georges insists on the similarities and the allegedly shared vision of both leaders to overcome the differences in their trajectory. For him, Bachir inspires affectivities of fusion, inspiration and communion, along the same tropes than those described in the evocations of Michel Aoun. Yet, Georges recognizes the polemical nature of his stand within the FPM. A similar positive depiction of Gemayel surfaces in another testimony of a FPM student activist whose family also originates from Zahleh:

My father told me about when the Palestinian fighters came to Zahleh. (...) Just in front of his house and his workplace, there were fights. Then, came the Syrians. At this moment, he decided to join the groups of local men who were defending the city with the help of the LF of Bachir Gemayel. (...) Despite being outnumbered, they prevailed. Bachir Gemayel then told that the victory in Zahleh helped him to become President. My father told me that when 
he was elected all the Churches rang their bells throughout the country. It was the greatest victory of the Lebanese Christians. (...) But he died only 21 days later. [Hani, student, 12.11.2007, Beirut]

Paula was born in the early 1970s, Georges in 1981 and Hani seven years later. They belong to successive generations and the political environments of their families were slightly different (Paula's father was in the Army, Georges' family was engaged in the Phalange, while Emile's father participated in the fighting in Zahleh). The spatial anchor of memory here plays a key role in activating the interplay of reception and identification with the leader. Indeed, the fate of Zahleh, a city situated near the Beirut-Damascus road, was instrumental in the political ascent of Bachir Gemayel. In December 1980 and April 1981, the town was besieged and underwent violent assaults from the Syrian Army. Zahleh's LF militants and Phalangists organized the defence of the city and local memory attributes and central role to Bachir Gemayel in their success. In fact, the episode was deeply inserted into a wider regional crisis between Israel and Syria and far from being victorious LF fighters were simply authorized to leave Zahleh without being prosecuted. The episode was transformed into a victory by Bachir Gemayel and composed a key part in the heroic narrative built around him.

Affectivities of the memory of Bachir Gemayel are in fragment. Contrary to Michel Aoun, Gemayel does not integrate uniformly the various frames of collective memory. Although his character presents features of the Christian prophet, Bachir Gemayel does not instigate senses of fusion, inspiration nor communion uniformly. Instead, it divides within the FPM according to different repertoires: familial, local, partisan, generational, etc. As such, his figure highlights alternative social boundaries beyond partisan identification.

Ultimately, the evocations of Samir Geagea and Bachir Gemayel are composed in relation to the central figure of Michel Aoun. The dialogic narrations exposed in these reactions underline, by opposition or by contrast, the three affective registers sustaining the attachment to the leader. Still, the articulation of these repertoires is not without dissonances. Tensions arise, in particular in front of the character of Bachir Gemayel, which could lead to dis-alignment of the private memory with the collective narration of the past put forward in the party.

\section{Conclusions}

This article started from the question of the portraying of political leaders by their followers in contemporary Lebanon. Taking the example of Michel Aoun, it documented how the leader was 
commonly depicted as a (grand-)father, a hero, and a prophet. These repertoires expose three affective modes of memorialization, each built on a specific temporality. Together, fusion, inspiration and communion, compose the connection to the leader and to the group he is considered to personify. Shifting the focus to memory practices hence enables to understand how political communalities in Lebanon result from the articulation of affective ties with multiple social memories and temporalities. Attachment lies in the vacillating contact between the complex living memory of the individuals and the narrative identity of the group, which sustains an interpretation of the self - understood in the double meaning of allocation of signification and role performance - as a member of a community incarnated in its leader. In the light of such intricate construction, the capability of partisan leaders to maintain their currency becomes more understandable. All in all, relying on a micro-sociology of leadership illuminates the historical as well as emotional dynamics at the heart of political identification in Lebanon. Crucially, it enables to grasp political communalities in the Lebanese plural society beyond the influence of political organizations, their ideological constructions and the seemingly unchanging identities they pretend to perform.

\section{Funding}

The drafting of this work was supported by a research grant from the Department of Political Science and Contemporary History of the University of Turku, Finland.

\section{Disclosure statement}

No potential conflict of interest was reported by the author.

\footnotetext{
Notes

${ }^{1}$ Commonly presented as 'a civil war' the conflict in Lebanon between 1975 and 1990 was a series of wars whose actors, scope and intensity varied greatly. Accordingly, I refer to this period as the Lebanese wars - plural.

${ }^{2}$ See the recent work of Marie-Noëlle Abi-Yaghi, Myriam Catusse, and Miriam Younes, 'From Isqat an-Nizam at-Ta'ifi to the Garbage Crisis Movement: Political Identities and Antisectarian Movements', in Lebanon Facing the Arab Uprisings. Constraints and Adaptation, eds. Rosita Di Peri and Daniel Meier (London: Palgrave Mac Millan, 2016): 73-91.

${ }^{3}$ Arnold Hottinger, 'Zu'ama in Historical Perspective', in Politics in Lebanon, ed. Leonard Binder (New York, NY: John Wiley and Sons, 1966): 85-105.

${ }^{4}$ See: Michael Johnson, Class and Clients in Beirut: The Sunni Muslim Community and the Lebanese State (London: Ithica Press, 1986).
} 
${ }^{5}$ See: Michael Gilsenan, Lords of the Lebanese Marches: Violence and Narrative in an Arab Society (London: I.B. Tauris, 1996).

${ }^{6}$ Samir Khalaf, Civil and Uncivil Violence. A History of the Inter-Nationalization of Communal Conflict in Lebanon (New York, NY: Columbia University Press, 2002), 173.

${ }^{7}$ Gilsenan, Lords of the Lebanese Marches, 287.

${ }^{8}$ Sune Haugbolle, War and Memory in Lebanon (Cambridge: Cambridge University Press, 2010), 51.

${ }^{9}$ Myriam Catusse and Jamil Moawad, 'Les choix de Jbeil'[Jbeil's choices], in Métamorphose des figures du leadership au Liban. Champs et contrechamps des élections législatives de 2009 [Metamorphoses of leadership figures in Lebanon. Views and counterviews of the 2009 Parliamentary elections], eds. Myriam Catusse, Karam Karam, and Olfa Lamloum (Beirut: Presses de l'Ifpo-Lebanese Center for Policy Studies, 2011): 33-77. Studying the 2009 Parliamentary elections, they show how inter-partisan competition marginalized local elites.

${ }^{10}$ See in particular: Elizabeth Picard, 'Une Sociologie Politique Du Za'îm Libanais' [An Historical Sociology of the Lebanese Za'îm], in Histoire, sociétés et pouvoir aux Proche et Moyen Orients [History, societies and power in the Middle East], vol. 1, ed. Charles Chartouni (Paris: Paul Geuthner, 2001): 157-172.

${ }^{11}$ Franck Mermier and Sabrina Mervin, 'Introduction: Une approche anthropologique du leadership au Liban'[Introduction: An anthropological approach to leadership in Lebanon], in Leaders et partisans au Liban [Leaders and partisans in Lebanon], eds. Franck Mermier and Sabrina Mervin (Paris-Beirut: Karthala-Ifpo, 2012), 12-3.

12 Philippe Abirached, 'Charisme, pouvoir et communauté politique: la figure de Michel Aoun' [Charisma, power and political communality: the figure of Michel Aoun], in Leaders et partisans au Liban, eds. Franck Mermier and Sabrina Mervin (Paris-Beirut: Karthala-Ifpo, 2012), 38.

${ }^{13}$ Max Weber, The Theory of the Social and Economic Organization (New York, NY: Oxford University Press, 1947), 358.

${ }^{14}$ Ann Ruth Willner and Dorothy Willner, 'The Rise and Role of Charismatic Leaders', American Academy of Political and Social Science, no. 358, vol. 1 (1965): 77-88, 77.

15 Ann Ruth Willner, The Spellbinders: Charismatic Political Leadership (New Haven, CT: Yale University Press, 1984), 3.

${ }^{16}$ Michel Aoun shares features with other Lebanese political leaders. He nonetheless provides an interesting case as his leadership emerged uncharacteristically from a popular movement, which was kept alive in Lebanon during Aoun's absence, between 1990 and 2005. As such, it questions the role of memory in the construction of leadership. Moreover, the FPM as well as other Christian political movements remain largely understudied within the field of Lebanese politics, while Hezbollah in particular has received much more academic attention.

${ }^{17}$ The same portfolio was used for all interviews. It included the following Lebanese political figures: Michel Aoun, Sayyed Hasan Nasrallah (secretary general of Hezbollah), Rafiq Hariri (former prime minister assassinated in 2005), Bachir Gemayel (former militia leader and president of the Republic, assassinated in 1982), Samir Geagea (former militia leader and rival of Michel Aoun).

${ }^{18}$ Douglas Harper, Visual Sociology (London: Routledge, 2012), 155.

19 Marie-Claire Lavabre, Le Fil Rouge, Sociologie de la Mémoire Communiste [The Red Line, Sociology of the Communist Memory] (Paris: Presses de la FNSP, 1994), 297. 
${ }^{20}$ Reiner Keller, The Sociology of Knowledge Approach to Discourse (New York, NY: Springer, 2016).

${ }^{21}$ Margaret Somers, 'The Narrative Constitution of Identity: A Relational and Network Approach', Theory and Society 23, no. 5 (1994): 605-49, 621.

${ }^{22}$ Peter Berger and Thomas Luckmann, The Social Construction of Reality (New York, NY: Penguin Books, 1966), 113-4.

${ }^{23}$ Pierre Nora, Les lieux de mémoire [Memory spaces] (Paris: Gallimard, 1992).

${ }^{24}$ In this article, memory refers to a representation of the past sustained by social frames and collective imaginations originally described in the work of Maurice Halbwachs: La Mémoire Collective [The Collective Memory] (Paris: Seuil, 1997). As learning a language, remembering the past operates through mechanisms constructed outside the individual, in the society (ibid., 31).

${ }^{25}$ May Davie, 'Aoun ou le refus chrétien' [Aoun or the Christian refusal], Temps Modernes, no. 5367 (1991): 147-80, 148-52.

${ }^{26}$ Elizabeth Picard, Lebanon, a Shattered Country. Myths and Realities of the Wars in Lebanon (New York, NY: Holmes \& Meier, 2002), 139.

${ }^{27}$ Davie, 'Aoun ou le refus chrétien', 172.

${ }^{28}$ Paul Ricoeur, Time and Narrative, vol. 1 (Chicago, IL: The University of Chicago Press, 1984), XXXv.

${ }^{29}$ Memory practices are multiple: commemorations, visual productions, movies, songs, etc. Many of these practices include a narrative dimension. In this work, I focus specifically on the composition and the voicing of personal stories.

${ }^{30}$ Halbwachs, La Mémoire Collective, 84-5.

${ }^{31}$ Gérard Namer, 'Affectivité et temporalité de la mémoire'[Affectivity and temporality of memory], L'Homme et la Société 22, no. 90 (1988): 9-14, 10.

32 The phenomenon is widespread among other partisan groups in Lebanon.

${ }^{33}$ Elizabeth Picard, 'The Political Economy of Civil War in Lebanon', in War, Institutions and Social Change in the Middle East, ed. Steven Heydemann (Berkeley, CA: University of California Press, 2000), 11 .

${ }^{34}$ A succession of internal rebellions occurred during the 1980s, in particular the violent confrontation between Samir Geagea and Elie Hobeika in 1986.

${ }^{35}$ Eviatar Zerubavel, Time Maps. Collective Memory and the Social Shape of the Past (ChicagoLondon: The University of Chicago Press, 2003), 45.

${ }^{36}$ See in particular: Kamal Salibi, A House of Many Mansions. The History of Lebanon Reconsidered (Berkeley, CA: University of California Press, 1988).

${ }^{37}$ This concept derives from the notion of 'âmma (plebs) referring here to a series of popular uprisings among Maronite peasants between 1830 and 1860. Those rebellions were directed against dominant feudal families and led to a redefinition of the power structure within the Maronite community between three poles: the secular aristocracy, the Church that has traditionally played the role of mediator between the elite and the mass, and the people whose demands were in some occasions directly carried by popular leaders from the plebs, the most famous example being Tanios Shahine. See: Elizabeth Picard, 'Les dynamiques politiques des chrétiens au Liban. Changement de statut et crise du leadership' [The political dynamics among Christians in Lebanon. Status change and leadership crisis], Monde Arabe Maghreb-Machrek, 153 (1996): 3-21, 10-1. 
${ }^{38}$ Idem.

${ }^{39}$ Fiona McCallum, 'The Political Role of the Patriarch in the Contemporary Middle East', Middle Eastern Studies 43, no. 6 (2007): 923-40.

${ }^{40}$ Davie, ‘Aoun ou le refus chrétien', 158.

${ }^{41}$ In a TV interview on 11 November 2009.

${ }^{42}$ Saint Maroun is allegedly buried in Brad, in Northern Syria and celebrated on February 9.

${ }^{43}$ Abirached, 'Charisme, pouvoir et communauté politique: la figure de Michel Aoun', 47.

${ }^{44}$ These violent uprisings resulted from a growing political and economic competition between the two main populations living in Mount Lebanon, the Druzes and the Maronites. They reached their climax in the massacres of 1840 and 1860.

45 Picard, 'Les dynamiques politiques des chrétiens au Liban. Changement de statut et crise du leadership', 5.

${ }^{46}$ Cited in Tewfil Khalaf, 'The Phalange and the Maronite Community', in Essays on the Crisis in Lebanon, ed. Robert Owen (London: Ithica Press, 1976), 43.

${ }^{47}$ Lyna Elias, Les Chrétiens du Liban menacés de disparition ou le plan d'islamisation du Liban est en marche! [The Christians of Lebanon Threatened of Extinction or the Plan for the Islamization of Lebanon Has Started] (Beirut: Editions Libanaises, 2007).

${ }^{48}$ Elizabeth Picard, Lebanon, a Shattered Country, 139.

${ }^{49}$ Interview with Laura, student, 30 November 2010, Beirut.

${ }^{50}$ Cited in Karim Pakradouni, La paix manquée. Le mandat d'Elias Sarkis (1976-1982) [A missed opportunity for peace. The Sarkis presidency (1976-1982] (Beirut: FMA, 1984), 235.

${ }^{51}$ Picard, Lebanon, a Shattered Country, 152.

${ }^{52}$ Haugbolle, War and Memory in Lebanon, 53.

${ }^{53}$ Albert Hourani, 'Ideologies of Mountain and the City', in Essays on the Crisis in Lebanon, ed. Robert Owen (London: Ithica Press, 1976): 33-41. 